\title{
Reakce studentů na diskusní aktivity při online výuce neoborového anglického jazyka ${ }^{1}$
}

\author{
Student reactions to discussion tasks in online teaching of English for non-specialists \\ František Tůma
}

\begin{abstract}
Abstrakt: Příspěvek zkoumá vnímání online diskusních úkolů VŠ studenty. Pro kvantitativní vyhodnocení reakcí studentů byla použita data z dotazníkového šetření. Online diskusní úkoly byly zařazeny $\mathrm{v}$ kurzu neoborového anglického jazyka $\mathrm{s}$ cílem rozvíjet komunikační kompetenci na úrovni A2 dle SERRJ (2002). Studenti formou textové komunikace v malých skupinách řešili zadaný úkol prostřednictvím asynchronního diskusního fóra. Př́ispěvek shrnuje teoretická východiska, výzkumný design (př́padová studie) a vybrané výsledky z části výzkumu zaměřené na reakce studentů.
\end{abstract}

Klíčová slova: komunikační kompetence, výuka psaní, blended learning, př́ípadová studie

\begin{abstract}
The aim of this paper is to investigate the way in which university students perceive online discussion tasks. A questionnaire survey was used for quantitative evaluation of student reactions. Online discussion tasks were implemented in English as a foreign language course the aim of which was to develop communicative competence at the CEFR A2 level. Through text communication in small groups, students solved a task using an asynchronous discussion forum. This paper introduces theoretical background, research design (a case study) and selected results from the part focused on student reactions.
\end{abstract}

Keywords: communicative competence, teaching writing, blended learning, case study

\section{Potřeba dovednosti komunikovat online}

Jedním z požadavků na současné vzdělávání $\mathrm{v}$ informační společnosti je schopnost absolventů škol efektivně používat ICT pro komunikaci (Zounek, 2009). Další prioritou terciárního vzdělávání je př́prava studentů na uplatnění na mezinárodním trhu práce, a k tomu je nezbytná schopnost komunikovat v cizím jazyce. Předkládaná studie představuje jednu z možností, jak zkoumat rozvíjení dovednosti psaní u studentů prostřednictvím diskusních fór na internetu.

\section{Teoretická východiska}

Níže budou stručně představena lingvistická, pedagogicko-psychologická a technologická východiska ${ }^{2}$ pro rozvíjení dovednosti psaní online. Jazyk používaný při komunikaci zprostředkované počítačem (srov. Crystal, 2011) kombinuje znaky mluveného i psaného jazyka. Při textové komunikaci v diskusním fóru se vyžaduje, aby studenti mj. př̀měřeně správně a vhodně používali jazykové prostředky, které znají, pro vyjádření svého záměru

\footnotetext{
${ }^{1}$ Tento př́íspěvek byl podpořen grantem SGS TUL č. 5842/2011.

2 Tato východiska byla společně s výsledky pilotní studie $\mathrm{k}$ tomuto projektu podrobněji rozpracována jinde (Tůma, 2010).
} 
v psané formě. Asynchronní komunikace umožňuje, aby studenti svůj text před odesláním zkontrolovali, upravili a př́padně doplnili. Tyto strategie odpovídají dovednosti psaní (Brown, 2003, s. 221), proto bude v této studii komunikace prostřednictvím diskusního fóra pojímána jako psaní.

Ve výzkumu byl pro komunikační kompetenci zvolen kvůli své přehledné struktuře Bachmanův model (1990), jehož jazyková komponenta je rozdělena na složku organizační (tj. jazykové prostředky) a složku pragmatickou, kterou dále dělí na kompetenci ilokuční a sociolingvistickou. Ilokuční kompetence se skládá z jazykových funkcí, tj. záměrů, které uživatel jazyka sděluje. Koncept jazykových funkcí vychází z filosofie jazyka a pragmatiky.

Z pedagogicko-psychologického hlediska jsou při psaní zpráv ve fóru uplatňovány principy sociálního konstruktivismu (Williams \& Burden, 1997) a kooperativního učení (Johnson \& Johnson, 1994) v rámci sociokongnitivních vzdělávacích teorií (Bertrand, 1998).

Po technologické stránce je pro komunikaci použito asynchronní diskusní fórum v kurzu realizovaném formou blended learning, kdy je kombinována prezenční výuka a výuka online (Graham, 2006).

\section{Komunikační úkoly}

Výše uvedená východiska představují základ pro realizaci diskusních úkolů, ve kterých studenti v malých online skupinách řeší zadaný úkol, v rámci blended learning kurzu. Činnost učitele během diskuse spočívá v monitorování činnosti studentů. Na konci diskuse, kromě hodnocení účasti studentů, učitel analyzuje uzavřená diskusní vlákna a zaměřuje se především na jazykovou přesnost. S chybami pak lze pracovat např. pomocí remediálních cvičení. Taková řízená cvičení lze také efektivně realizovat v rámci online kurzu (srov. Zounek, 2009).

Při aktivní účasti v takto vedených diskusních úkolech lze předpokládat, že u studentů dojde k rozvoji komunikační kompetence, a tedy i formování jejich písemného projevu. Skehan (2003) rozlišuje tři aspekty projevu: accuracy (přesnost), fluency (plynulost, lze vyjádřit i jako rychlost psaní) a complexity (složitost textu). Díky reálné a smysluplné komunikaci a také určité novosti či nevšednosti úkolů pro studenty lze předpokládat, že studenti budou diskusní aktivity přijímat převážně pozitivně.

\section{Metodologie}

Výzkumné otázky spojené s implementací takto koncipovaných diskusních úkolů do blended kurzu je možné, jak bylo naznačeno $\mathrm{v}$ předchozím odstavci, rozdělit do dvou rovin lingvistické (tj. zda vůbec a k jakému posunu došlo v oblasti komunikační kompetence ${ }^{3}$ ) a psychologické (jak studenti reagují na předkládané aktivity, proč jsou aktivity některými studenty vnímány výrazně pozitivně/negativně).

Klíčovou metodologickou otázkou pro tuto studii je volba vhodného výzkumného designu. Úkoly jsou realizovány $\mathrm{v}$ rámci online komponenty blended kurzu, kdy nad účastí studentů prakticky neexistuje př́má kontrola, protože studenti pracují z domova v různých časech. Vzhledem k charakteru výzkumných otázek a šíři záběru této studie byla zvolena metodologie př́ípadové studie (Hendl, 2005; Yin, 2009). Online komponenta blended kurzu s diskusními

\footnotetext{
${ }^{3} \mathrm{Tj}$. komunikační kompetence celkově, a také přesnosti a složitosti písemného projevu u studentů. Plynulost písemného projevu v této studii nebude dále diskutována, nebot’ asynchronní forma komunikace v principu neumožňuje zachytit čas trávený nad psaním př́spěvku.
} 
úkoly představuje kontext pro př́padovou studii a skupina studentů s danou vstupní úrovní cizojazyčné kompetence tvoří zkoumaný případ. V rámci tohoto př́ípadu (skupiny studentů) pak lze zkoumat změny v oblasti komunikační kompetence a vnímání diskusních úkolů studenty. Pro hlubší pochopení zkoumané problematiky je možné v rámci př́ípadu záměrně vybrat studenty a chápat je jako jednotku pro analýzu. Podle Yina (2009, s. 46) se tedy jedná o prrípadovou studii s vnořenými jednotkami pro analýzu.

Cílem případové studie je zobecnění k teorii, tedy analytická generalizace (Yin, 2009, s. 3839). Teorie slouží jako rámec, ke kterému se cíleně nasbíraná empirická data zobecňují. Pro sběr dat bylo použito jak kvantitativních, tak kvalitativních metod, jejichž sled a provázanost jsou naznačeny na obr. č. 1. Následuje stručný popis jednotlivých metod sběru dat.

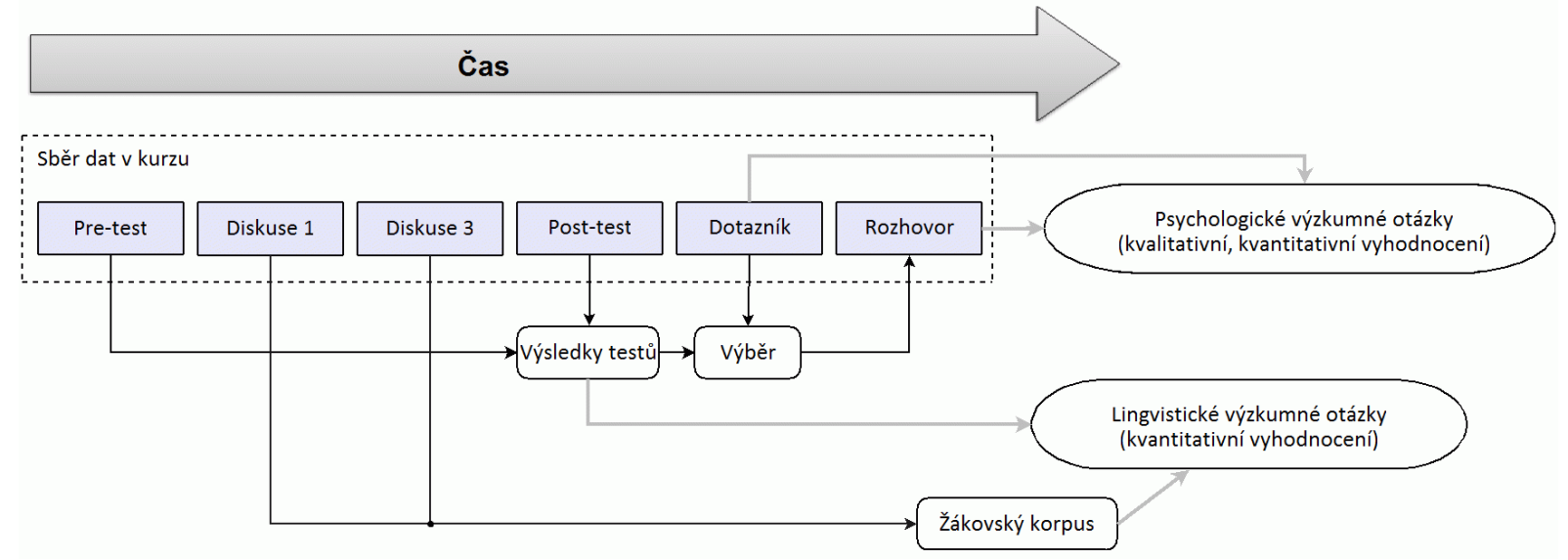

Obrázek 1. Průběh sběru a vyhodnocování dat.

Didaktický test: pre-test a post-test. Pro výběr jedinců do př́ípadové studie a pro vyhodnocení posunu v komunikační kompetenci byly použity testy KET ${ }^{4}$ pro čtení a psaní jako pre- a posttesty. Pro př́padovou studii byli vybráni studenti, kteří dosáhli výsledku mezi 50 a $85 \%$ $\mathrm{v}$ pre-testech.

Žákovský korpus ${ }^{5}$ byl vytvořen $\mathrm{z}$ textů psaných studenty v rámci vybraných realizovaných diskusí ${ }^{6}$, které odrážejí stav na začátku a na konci kurzu. Jejich srovnáním je možné určit změny v oblasti jazykové přesnosti a složitosti, protože promluvy studentů byly anotovány z hlediska syntaktické složitosti a chyb.

Závěrečný dotazník zjišstoval reakce a vnímání vybraných aspektů diskusí studenty. Jeho konstrukce a výsledky šetření jsou prezentovány níže.

Rozhovory pomocí návodu (Hendl, 2005). Tyto rozhovory byly provedeny s jedinci, kteří byli vybráni metodou prostého účelového výběru (Miovský, 2006, s. 136), tj. tací studenti, kteří splnili alespoň jedno z následujících kritérií: (1) výsledky pre- a post-testů: jedinci, u kterých došlo k výraznému zlepšení na konci kurzu, a ti, u kterých došlo jen k malé změně, (2) dotazníky: jedinci, kteří vnímali diskusní aktivity velmi pozitivně/negativně. Cílem rozhovoru bylo hlouběji pochopit a dokreslit kvantitativní data získaná z testů a dotazníků (Miovský, 2006, s. 33).

\footnotetext{
${ }^{4}$ Key English Test - standardizované testy na úrovni A2 dle SERRJ (2002).

5 Anglicky learner corpus, k tvorbě žákovského korpusu a chybovým anotacím viz Biber et al. (2011), Škodová (2009) aj.

${ }^{6}$ V kurzu proběhly tři diskusní úkoly, pro tvorbu korpusu byla zvolena první a třetí diskuse.
} 


\subsection{Smíšený design pro vyhodnocení reakcí studentů}

Reakce studentů byly zjišt'ovány formou dotazníkového šetření a následných rozhovorů pomocí návodů.

Východiskem pro konstrukci dotazníků byly výpovědi 14 studentů z polořízených rozhovorů cílených na zjištění reakcí studentů z pilotní studie, která byla provedena $\mathrm{v}$ akademickém roce 2008/09. Rozhovory trvaly 15-25 minut. Studenti vyjádřili především pozitivní reakce na diskusní úkoly, jejich výpovědi byly zaznamenány na diktafon a analyzovány (Hendl, 2005, s. 226-229, 236), přičemž byly vymezeny kategorie pro kvantitativní ověření pomocí dotazníku ve vlastním výzkumu v následujícím roce, jehož dílčí výsledky jsou prezentovány níže. Pro dokreslení kvantitativních dat pak byly s vybranými jedinci provedeny rozhovory. V oblasti výzkumu reakcí studentů tedy byla zvolena smíšená metodologie dle schématu QUAL $\rightarrow$ QUAN $\rightarrow$ QUAL (Hendl, 2005, s. 280).

$\mathrm{Z}$ důvodu oddělení studentů spadajících do př́ípadové studie od ostatních studentů v kurzu, a také kvůli možnosti cíleného výběru jedinců pro následující rozhovor, byly dotazníky neanonymní. Vybrané výsledky šetření jsou shrnuty níže.

\section{Reakce studentů}

Empirické šetření bylo realizováno $\mathrm{v}$ kurzu angličtiny pro nefilology $\mathrm{v}$ letním semestru akademického roku 2010/11 ${ }^{7}$. Z 33 studentů, kteří se do kurzu zapsali, bylo po pre-testu pro př́padovou studii vybráno 18 studentů. Tito studenti byli náhodně rozděleni do skupin po 5-6 účastnících, ve kterých řešili připravené úkoly. Všech 18 studentů vyplnilo v závěru kurzu dotazníky, jejichž vybrané výstupy budou představeny níže.

První z otázek byla cílena na vnímanou přínosnost diskusních úkolů. 8 studentů vypovědělo, že diskuse byly velmi př́nosné, 9 studentů považovalo diskuse za spiše př́nosné a 1 studentka je pokládala za spiše neprínosné.

Součástí dotazníku byl panel otázek cílených na vnímání zábavnosti u vybraných aspektů diskusí. Studenti měli vyjádřit svůj (ne)souhlas s výroky pomocí pětistupňové Likertovy škály. Odpovědím studentů byla přiřazena čísla od 1 (zcela nesouhlasím) do 5 (zcela souhlasim) a všechny odpovědi pro daný výrok byly následovně zprůměrovány. Výsledky tří nejobecnějších položek cílených na vnímání diskusí byly následující:

- Účast v samotné diskusi mé bavila: 3,72

- Bylo zajímavé čist si príspěvky ostatních: 4,11

- Bavilo mě reagovat na př́spěvky druhých: 3,89

Vybraní studenti byli přizváni k rozhovoru (jednalo se o celkem 6 studentů, kteří byli vybráni na základě kritérií uvedených výše). V rozhovorech byly identifikovány individuální odlišnosti mezi studenty (učební styly, osobnostní rysy), skupinová specifika a (ne)plánování času pro účast $\mathrm{v}$ diskusi jako faktory, které pravděpodobně měly vliv na jejich vnímání aktivit. Rozsah tohoto př́spěvku, bohužel, neumožňuje podrobněji rozvést výpovědi jednotlivých studentů.

\section{Závěr}

V př́spěvku byla uvedena teoretická a metodologická východiska pro realizaci a výzkum diskusních úkolů cílených na rozvoj komunikační kompetence v cizím jazyce. Jak je patrno

\footnotetext{
${ }^{7}$ Všichni vybraní studenti absolvovali předcházející kurz angličtiny v zimním semestru, ve kterém se seznámili s prostředím Moodle. Tím byly minimalizovány případné technické problémy.
} 
z vybraných výsledků výzkumu cíleného na vnímání diskuse v online skupinách, studenti přijímali realizované diskusní úkoly pozitivně. Ve zkoumaném prŕípadu navíc došlo celkově $\mathrm{k}$ rozvoji komunikační kompetence ${ }^{8}$.

Na základě výpovědí studentů a výsledků testů lze uvést, že obdržená data korespondují s teoretickými předpoklady a tedy potvrzují jejich platnost. Tato studie tedy částečně přispívá $\mathrm{k}$ problematice implementace ICT do výuky v rámci sociokognitivních vzdělávacích teorií a potvrzuje přínosnost ICT ve vzdělávání.

\section{Literatura}

Bachman, L. F. (1990). Fundamental considerations in language testing. Oxford: Oxford University Press.

Bertrand, Y. (1998). Soudobé teorie vzdělávání. Praha: Portál.

Biber, D., Reppen, R., \& Friginal, E. (2011). Research in corpus linguistics. In R. Kaplan (Ed.), The Oxford handbook of applied linguistics (pp. 548-567). Oxford: Oxford University Press.

Brown, H. D. (2003). Language assessment: Principles and classroom practice. White Plains: Pearson.

Crystal, D. (2011). Internet linguistics: A student guide. London: Routledge.

Graham, C. R. (2006). Blended learning systems: Definition, current trends, and future directions. The handbook of blended learning: Global perspectives, local designs (3-21). San Francisco: Pfeiffer.

Hendl, J. (2005). Kvalitativní výzkum. Praha: Portál.

Johnson, D. W., \& Johnson, R. T. (1994). Learning together and alone. Cooperative, competitive, and individualistic learning. Needham Heights: Allyn and Bacon.

Miovský, M. (2006). Kvalitativni prístup a metody v psychologickém výzkumu. Praha: Grada.

Skehan, P. (2003). Task-Based instruction. Language Teaching, 36(1), 1-14.

Společný evropský referenční rámec pro jazyky. (2002). Olomouc: UP v Olomouci.

Škodová, S. (2009). Možnosti zachycení chyb v tzv. žákovských korpusech. In O. Uličný (Ed.), Eurolingua \& Eurolitteraria 2009 (pp. 197-204). Liberec: TU v Liberci.

Tůma, F. (2010). Methodological considerations in developing online communication skills in English language courses. Proceedings of the 9th European conference on e-learning (pp. 769-776). Porto.

Williams, M., \& Burden, R. L. (1997). Psychology for language teachers: a social constructivist approach. Cambridge: Cambridge University Press.

Yin, R. K. (2009). Case study research: Design and methods. Thousand Oaks: Sage Publications.

Zounek, J. (2009). E-learning-jedna z podob učení v moderní společnosti. Brno: MU.

\footnotetext{
${ }^{8} \mathrm{U}$ zkoumaného př́ípadu došlo $\mathrm{k}$ nárůstu průměrného celkového výsledku ze 76 \% (průměrné celkové výsledkypre-test) na $87 \%$ (post-test), výsledky testů budou podrobněji publikovány jinde.
} 


\section{Kontakt}

Mgr. František Tůma

Technická univerzita v Liberci

Fakulta př́rodovědně-humanitní a pedagogická, Katedra anglického jazyka

Voroněžská 1329/13, 46001 Liberec 1

e-mail: frantisek.tuma@tul.cz

\section{Bibliografické údaje}

Tůma, F. (2011). Reakce studentů na diskusní aktivity při online výuce neoborového anglického jazyka. In T. Janík, P. Knecht, \& S. Šebestová (Eds.), Smíšený design v pedagogickém výzkumu: Sborník př́spěvků z 19. výroční konference České asociace pedagogického výzkumu (s. 505-510). Brno: Masarykova univerzita.

Dostupné z: http://www.ped.muni.cz/capv2011/sbornikprispevku/tuma.pdf doi: 10.5817/PdF.P210-CAPV-2012-78 